\title{
EFFECT OF TRANSCENDENTAL MEDITATION ON PULSE RATE AND BLOOD PRESSURE
}

\author{
MENDHURWAR S.S. ${ }^{*}$ AND GADAKARI J.G. ${ }^{2}$ \\ ${ }^{1}$ Department of Physiology, Padmashree Dr. D.Y. Patil Medical College, Hospital and Research Center, Nerul, Navi Mumbai \\ 2Department of Physiology, Seth G. S. Medical College, Parel, Mumbai \\ *Corresponding Author: Email- sadhana.mendhurwar@gmail.com
}

Received: December 12, 2011; Accepted: January 15, 2012

\begin{abstract}
Disorders of cardiovascular system especially hypertension and ischemic heart disease are leading causes of death all over the world. In today's life, stress is inevitable. Stress is one of the important factors precipitating the above diseases. In preventing such diseases therefore one must try to reduce the stress. Meditation is one of the important tools in reducing the stress. In the present study therefore its effect on the pulse rate and blood pressure were studied. Effect of 6 weeks of TM (Transcendental Meditation) practice was studied on pulse rate and blood pressure in 37 male and 38 female volunteers. There was significant reduction in pulse rate in both sexes indicating reduced sympathetic activity. However there was no significant change in systolic or diastolic blood pressure. In the present study TM was practiced only for 6 weeks. Prolonged practice of TM may be more effective and may also cause reduction in blood pressure. Effects of practicing TM for a longer time should be studied.
\end{abstract}

Key Words- Transcendental Meditation, Blood pressure, Pulse rate

Citation: Mendhurwar SS and Gadakari JG (2012) Effect of transcendental meditation on pulse rate and blood pressure. International Journal of Medical and Clinical Research, ISSN: 0976-5530 \& E-ISSN:0976-5549, Volume 3, Issue 1, 2012, pp-107-109.

Copyright: Copyright@2012 Mendhurwar SS and Gadakari JG. This is an open-access article distributed under the terms of the Creative Commons Attribution License, which permits unrestricted use, distribution, and reproduction in any medium, provided the original author and source are credited.

\section{Introduction}

Medical science aims at achieving optimum physical and mental health. Yoga also has same aim but mainly stresses on promotive aspects dealing with "inner world" or mind [1] Linkages between body and mind are now well established. Therefore it is quiet likely that yoga would help science in achieving the goal of maintaining optimum functions of mind and body of the individual .Before one can use Yogic practices for this purpose their effect should be proved scientifically.

There are several types of yogic practices amongst which meditation is one of the important means of achieving calmness. Stress is inevitable part of life and it causes several ill effects on the body [27]

Meditation technique reduces anxiety $[8,9,10]$ and therefore may be useful in preventing and treating some psychological diseases.

Many workers have studied the effects of different yogic practices on cardiovascular functions and therapeutic effects of them in cardiovascular diseases [11- 17]

Especially hypertension is a common disease which may be caused by constant stress. In the present study therefore effect of Transcendental meditation on pulse rate and blood pressure were studied. For the present study Transcendental Meditation was chosen as it is the most common form of meditation involving mental repetition of mantra and is easy to learn.

\section{Methods and Materials}

Seventy five volunteers were chosen for the present study. Thirty seven volunteers were males and thirty eight were females. Following criteria were used for selecting the volunteers.

- Age between 20-40 years

- Co-operative subjects likely to adhere to the scheduled programme

- No history of heart attack, hypertension, diabetes or any other chronic illness that required regular pharmacological treatment.

- No history of major psychiatry disorders, current alcohol abuse/ dependency disorders.

- Consent was obtained from each volunteer after explaining the entire study plan. An approval of institutional ethics committee was obtained before commencing the study. Following parameters were recorded from each volunteer.

- Name, age, sex 
- Height and weight

- Pulse rate - Placing three fingers on the radial artery pulse rate at complete rest was measured for full one minute for three times and average was taken and noted as resting pulse rate before the meditation programme(control readings)

1. Blood pressure - Volunteer was asked to lie on a bed for fifteen minutes .Then with the help of sphygmomanometer systolic and diastolic pressures were recorded. Blood pressure was measured three times and average was taken and noted as resting systolic and diastolic pressures before the meditation programme (control readings)

Volunteers were then divided into two groups.

Group I contained 37 males and group II contained 38 females. Each group underwent training session for 6 weeks and practicing session for 6 weeks.

\section{Training session}

In this session volunteers were trained for Transcendental meditation (TM) Technique was taught by giving individualized personal instructions. Technique of Transcendental meditation (TM) was taught as given below [18-21]. Meditator sits quietly in a comfortable position with his/her back erect, eyes closed (preferably a lotus position) and takes slow ,deep breaths.

Meditator silently repeats a mystical Sanskrit sound (mantra) .Repetition of 'mantra' is supposed to be effortless. Meditator neither attempts to concentrate on sound nor attempts to prevent his /her attention from wavering. He/she is merely instructed to 'favour the mantra' and is frequently adjured to take it easily as it comes during the period of instruction. Gradually meditator learns to maintain awareness of 'mantra' excluding other thoughts, external influences and desires.

\section{Practicing session}

- All the volunteers practiced TM for 20 minutes every morning for 6 weeks.

- At the end of practicing session pulse rate and blood pressure of each volunteer were measured as before. The readings obtained were compared with control readings recorded before the sessions. Student's t test was applied for statistical analysis of the results.

\section{Results}

- There was highly significant fall in pulse rate in males and females after the session. (Table 1)

Table -1 Comparison of Pulse Rate per Minute - Before and After the Sessions in Males and Females

\begin{tabular}{|lllllllll|}
\hline Groups & & $\begin{array}{l}\text { No. of } \\
\text { Observa- } \\
\text { tions }\end{array}$ & $\begin{array}{l}\text { Mean } \\
(\mathbf{x})\end{array}$ & S.D. & S.E. & $\begin{array}{l}\text { t- } \\
\text { value }\end{array}$ & p-value & $\begin{array}{l}\text { Signifi- } \\
\text { cance }\end{array}$ \\
\hline Males & Before & 37 & 77.41 & 3.07 & 0.309 & 24.48 & $<0.0004$ & Highly \\
& After & 37 & 69.84 & 1.42 & & & & significant \\
Fe- & Before & 38 & 76.55 & 3.65 & 0.688 & 9.869 & $<0.0004$ & $\begin{array}{l}\text { Highly } \\
\text { significant }\end{array}$ \\
\hline
\end{tabular}

- Comparing results in males and females did not show statistically significant difference indicating that males and females had equal fall in pulse rate and they responded equally to the session. (Table 2)
Table - 2 Comparison of effects of Pulse Rate per Minute - in Males and Females

\begin{tabular}{|llllllll|}
\hline Groups & $\begin{array}{l}\text { No. of } \\
\text { Observa- }\end{array}$ & Mean $(\mathrm{x})$ & S.D. & S.E. & $\begin{array}{l}\mathrm{t} \text { - } \\
\text { value }\end{array}$ & $\begin{array}{l}\mathrm{p} \text { - } \\
\text { value }\end{array}$ & $\begin{array}{l}\text { Signifi- } \\
\text { cance }\end{array}$ \\
\hline Males & 37 & 6.8 & 2.5 & 0.589 & 1.3578 & 0.1738 & $\begin{array}{l}\text { Not signifi- } \\
\text { cant }\end{array}$ \\
\hline Females & 38 & 7.6 & 2.6 & & & & \\
\hline
\end{tabular}

- There was no significant change in systolic and diastolic pressures after the session. (Table 3 and Table 4)

Table 3- Comparison of systolic pressure in $\mathrm{mm}$ of $\mathrm{Hg}$ before and after the sessions in Males and Females

\begin{tabular}{|c|c|c|c|c|c|c|c|c|}
\hline Groups & & $\begin{array}{l}\text { No. of } \\
\text { Obser- } \\
\text { vations }\end{array}$ & $\begin{array}{l}\text { Mean } \\
(\mathbf{x})\end{array}$ & S.D. & S.E. & $\begin{array}{l}\mathrm{t} \text { - } \\
\text { value }\end{array}$ & $\mathrm{p}$-value & $\begin{array}{l}\text { Signifi- } \\
\text { cance }\end{array}$ \\
\hline \multirow[t]{2}{*}{ Males } & Before & 37 & 124.59 & 4.716 & \multirow[t]{2}{*}{1.005} & \multirow[t]{2}{*}{1.018} & \multirow[t]{2}{*}{0.3076} & \multirow{4}{*}{$\begin{array}{l}\text { Not } \\
\text { signifi- } \\
\text { cant } \\
\text { Not } \\
\text { signifi- } \\
\text { cant }\end{array}$} \\
\hline & After & 37 & 123.56 & 3.890 & & & & \\
\hline \multirow{2}{*}{$\begin{array}{l}\mathrm{Fe}- \\
\text { males }\end{array}$} & Before & 38 & 123.79 & 6.530 & \multirow[t]{2}{*}{1.45} & \multirow[t]{2}{*}{0.724} & \multirow[t]{2}{*}{0.4716} & \\
\hline & After & 38 & 122.74 & 6.090 & & & & \\
\hline
\end{tabular}

Table 4- Comparison of diastolic pressure in $\mathrm{mm}$ of $\mathrm{Hg}$ before and after the sessions in Males and Females

\begin{tabular}{|lllllllll|}
\hline Groups & & $\begin{array}{l}\text { No. of } \\
\text { Obser- } \\
\text { vations }\end{array}$ & $\begin{array}{l}\text { Mean } \\
(\mathbf{x})\end{array}$ & S.D. & S.E. & $\begin{array}{l}\text { t- } \\
\text { value }\end{array}$ & $\begin{array}{l}\text { p- } \\
\text { value }\end{array}$ & $\begin{array}{l}\text { Signifi- } \\
\text { cance }\end{array}$ \\
Males & Before & 37 & 84.59 & 4.70 & 1.005 & 1.018 & 0.3076 & $\begin{array}{l}\text { Not } \\
\text { significant }\end{array}$ \\
& After & 37 & 84.56 & 3.80 & & & & $\begin{array}{l}\text { Not } \\
\text { se- }\end{array}$ \\
Before & 38 & 81.89 & 6.43 & 1.439 & 0.0 & 1.0 & & \\
males & After & 38 & 81.89 & 6.10 & & & & \\
\hline
\end{tabular}

\section{Discussion}

Results of the present study indicate that there is highly significant decrease in pulse rate after TM session in both males and females. There is no significant difference in the effect caused by meditation in males and females indicating that the sessions have same effect in males and females.

Several workers have studied effects of meditation on heart/pulse rate.

Shirely Tells et al [22] reported decreased heart rate in subjects mentally repeating meaningful and non meaningful syllable. According to her repeating non meaningful syllable is equivalent to TM and decreased heart rate reported is due to decreased sympathetic activity.

Ayesha A. Khanam et al [23] also reported reduction in basal heart rate as an effect of yogic asanas, meditation, Anulom and vilom breathing. Total period of these yogic exercises in this study was of seven days. In such a small period there was significant decrease in heart rate and it was due to reduced sympathetic activity according to the investigators.

Shirley Tells et al [24] found significant decrease in heart rate in subjects doing 'OM' meditation. This decrease in the heart rate is attributed to psychophysiological relaxation.

Robert K.Wallace [12] also reported significant reduction in heart rate during and after TM in his volunteers. He concluded that TM reduces physical and mental tension.

V.A. Barnes et al [15] studied acute effects of TM and found reduction in temperature, pulse rate, respiratory rate during TM. According to him practice of TM affects the thinking process to a more settled resulting in what is called as 'Restful alertness'. 
However Putai Jin [22] studied effects of Taichi (a type of meditation) on heart rate and found significant increase in heart rate in volunteers having practice of Taichi for one year. Thus the effect was similar to that of physical exercise.

Ruth R.M. et al [26] found that after practice of TM for two years there was no effect on heart rate in his volunteers and therefore he does not support the hypothesis that TM is a state of reduced sympathetic activity.

Majority of the workers have shown the significant reduction in resting pulse rate as an effect of meditation and the present study aggress with them.

In the present study there was significant decrease in pulse rate after practicing TM for 6 weeks. The observed result is due to physical and mental relaxation as an effect of TM which also results in reduction of sympathetic activity and trend of autonomic equilibrium to gradually shift towards parasympathetic dominance.

In the present study effect of meditation on systolic and diastolic blood pressure is studied. Several workers have studied the effect of meditation on blood pressure.

Bary Backwell et al [14] studied effect of 12 weeks of TM practice and found significant reduction in blood pressure and anxiety score. He suggested that TM may be a therapeutic adjunct in patients with hypertension.

Vernon A Barnes et al [15] studied acute effects of TM .He reported that there is significant decrease in systolic pressure, temperature, pulse rate and respiratory rate during TM. In his opinion TM affects thinking process to more settled state, resulting in what is called as 'restful alertness' .Many investigators have demonstrated enhanced neurophysiological function, decreased respiratory rate, decreased sympathetic tone and inhibition of hypothalamuspituitary-adrenocortical systems as an effect of TM. Such physiological changes are associated with concomitant fall in blood pressure.

B.L. Agarwal and A. Kharbanda [16] studied effect of 6 months TM practice and reported fall in systolic and diastolic pressure in patients with mild and moderate hypertension.

R.K. Wallace et al [18] have studied effects of long term and short term TM practice on blood pressure. Volunteers practicing TM for less than five years were considered to be having short term practice of TM whereas volunteers practicing TM for more than five years in long term group. In both short and long term groups there was significant decrease in blood pressure. But in long term TM practitioners more significant lowering in blood pressure occurred as compared to short term practitioners in males and females of different age groups. They proposed that TM should be widely employed.

Results obtained in the TM group of present study are contrary to the effect obtained by above investigators. Six weeks TM practice has not affected systolic and diastolic pressures in both sexes. All the above investigators have reported reduction in blood pressure either during TM or in persons practicing TM for long time. Probably long term TM practice seems to affect the vasomotor tone and blood pressure. In the present study duration of practice was too short and therefore has not affected the blood pressure.

\section{Conclusion}

Practice of TM for 6 weeks reduced pulse rate significantly in males and females but has not affected either systolic or diastolic blood pressure. Effect of long term practice of TM should be studied for proving the value of TM in improvement of cardiovascular efficiency. The duration for which TM should be practiced for effectiveness also should be studied. Now days in busy life duration of practice should be as less as possible, if one wants everyone to practice TM for a long period. The effective regime requiring minimum daily time should be noted.

\section{References}

[1] Anand B.K. (1991) Ind .J. Physiol. Pharmacol 35(2): 84-87.

[2] Christensen N.J., Jensen F.W. (1994) Psychosomatic Medicine 56: 77-83.

[3] Johansson Gunnar, Laaksu M.L., Karonen S.L, Peder Mikael (1987) Psychosomatic Medicine 1987; 49: 390-396.

[4] Morell E.M., Hollands worth J.G (1986) Psychosomatic Medicine $48(3 / 4) ; 270-277$.

[5] Agarwal V, Gupta Bhavesh, Singhal Usha, Bajpai S.K. (1997) Indian J. Physiol Pharmacol 41 (4): 404-408.

[6] Rabkin J.G., Struening E.L. (1982) Science 215: 1013 - 1020.

[7] Suls H., Fletcher B. (1985) Psychosomatic Medicine 47(5): 469-481.

[8] Schwartz G.E., Davidson R.J., Goleman D.J. (1978) Psychosomatic Medicine 40(4) : 321-328.

[9] Irving Krish, Henry David (1979) Journal of consulting and clinical psychology 47(3) 536-541.

[10]Ginz Harris, Johnson S.B. (1980) Journal of consulting and clinical psychology 48(2) 186-194.

[11]Davidson D.M, Winchester M.A, Tayler C.B, Alderman E.A. Ingels N.B. (1979) Psychosomatic medicine 41(4): 303- 309.

[12]Wallace R.K. (1970) Science 167: 1751-1754.

[13]Christoph Paul, Luborsky L., Kron R., Fishman H. (1978) Journal of psychosomatic research 22: 493-501.

[14]Blackwell Barry, Haneson Irwin, Bloomfield Saul Magenheim Herbert, Gartside peter, Sanford Nidich, Robinson Ann, Zigler Ronald (1976) Lancet 223-226.

[15]Barnes V.A., Treiber F.A., Turner Rick, Davis Harry, Strong W.B (1999) Psychosomatic medicine 61: 525- 531.

[16]Agarwal B.L., Kharbanda K. (1981) J .Asso.Phys.Ind 29: 594596.

[17]Jacob R.G., Shapiro A.D., Porster O., Hara S., Kruger A., Gatsonis C., Ding Y. (1992) Psychosomatic Medicine 54: 87- 101.

[18]Walton K.G., Pugh Nirmal D.C. (1977) Indian J. Physiol Pharmacol 39(1) 3-36.

[19]Morse D.R., martin J.S., Furst M.L., Dubin L.L. (1977) Psychosomatic medicine 39(5) 304-322.

[20]Farrow J.T., Herbert Russell (1982) Psychosomatic medicine 44 (2) 133-153.

[21]West Michael (1979) British J. Psychiat. 135: 457-467.

[22]Telles Shierly, Nagarathna R., Nagendra H.R. (1998) Indian J. Physiol Pharmacol 42 (10): 57-63.

[23]Khanam A.A, Sachdeva Usha, Guleria R, Deepak K.K. (1996) Indian J. Physiol Pharmacol 40(4) 318- 324.

[24]Telles Shirely, Nagarathna R., Nagendra H.R. (1995) Indian J. Physiol Pharmacol 39(4): 418-420Research (1989) 33 (2): 197206.

[25]Ruth R.M., Parra J., McCann D.S., Vander A.J. (1979) Psychosomatic Medicine (1) 50-54.

[26]Wallace R.K., Silver J., Mills P.J., Dillbeck M.G., Wagoner D.E. (1983) Psychosomatic Medicine 45(1): 41-46. 